\title{
Kenapa Wajib Pajak UMKM Enggan Membayar Pajak Penghasilan?
}

\author{
Ni Putu Rossica Sari ${ }^{1}$ \\ Undiknas Graduate School, Universitas \\ Pendidikan Nasional, Indonesia \\ Email: rossicasari@gmail.com
}

\author{
Agus Fredy Maradona ${ }^{2}$ \\ Fakultas Ekonomi dan Bisnis, \\ Universitas Pendidikan Nasional, \\ Indonesia
}

\begin{abstract}
ABSTRAK
Dalam rangka memperbesar jumlah pendapatan pajak dari sektor UMKM, pemerintah telah menurunkan tarif pajak penghasilan bagi UMKM melalui PP Nomor 23 Tahun 2018. Akan tetapi, di sejumlah daerah, pembayaran pajak penghasilan dari UMKM justru menurun. Tujuan penelitian iniadalah untuk menginvestigasi penyebab belum optimalnya tingkat kepatuhan wajib pajak UMKM dalam melaksanakan kewajiban pembayaran pajak penghasilan, dengan menggunakan theory of planned behaviour sebagai kerangka teori. Penelitian ini merupakan studi eksplorasi yang menggunakan pendekatan kualitatif dengan setting penelitian berupa wilayah kerja KPP Pratama Singaraja. Hasil penelitian menunjukkan bahwa kesadaran wajib pajak akan substansi dari pajak bagi keuangan negara merupakan faktor yang paling esensial dalam menentukan tingkat kepatuhan wajib pajak UMKM. Hasil penelitian ini memberi implikasi penting bagi otoritas perpajakan dalam rangka meningkatkan kepatuhan UMKM dalam melaksanakan kewajiban perpajakan.
\end{abstract}

Kata Kunci: Kepatuhan Wajib Pajak; UMKM; PP Nomor 23 Tahun 2018; Kesadaran Wajib Pajak; Theory Of Planned Behavior.

\section{Why Are SME Taxpayers Reluctant To Pay Income Tax?}

\section{ABSTRACT}

To boost tax revenues from the SMEs sector, the government has reduced the income tax rate for SMEs through the issuance of PP Number 23 of 2018. Nevertheless, in some regions, the tax revenues from the SMEs sector have, unexpectedly, decreased. The purpose of this study is to investigate the reasons for the lack of compliance by SME taxpayers, using the theory of planned behaviour as a theoretical framework. This study employed an exploratory design using a qualitative approach, in which the service areas of the Singaraja tax office served as the research setting. The results of this study show that the primary determinant of SME taxpayers' compliance in paying income tax is the taxpayers' consciousness concerning the importance of tax revenues for the country's financial wellbeing. This finding provides significant implications for the Indonesian tax authority concerning their mission to increase the compliancelevel of SMEs taxpayers in fulfilling their tax obligations.

Keywords: $\quad$ Taxpayer Compliance; SME; PP Number 23 Of 2018; Taxpayer Awareness; Theory Of Planned Behaviour.

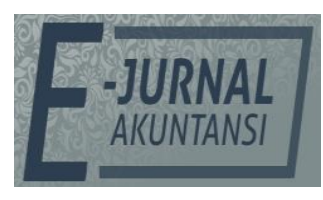

E-JA

e-Jurnal Akuntansi e-ISSN 2302-8556

Vol. 30 No. 6

Denpasar, Juni 2020 Hal.1561-1574

Artikel Masuk:

8 Mei 2020

Tanggal Diterima: 25 Juni 2020

The Article is Available in: https://ojs.unud.ac.id/index.php/Akuntansi/index 


\section{PENDAHULUAN}

Peran pajak dalam keberlangsungan roda pemerintahan dan pembangunan suatu negara sangatlah penting mengingat pajak memberikan sumbangsih terbesar bagi pemasukan nasional suatu negara. Sebagai ujung tombak penerimaan negara, kontribusi pajak sangatlah potensial (Tene et al., 2017). Pajak merupakan iuran dari masyarakat kepada negara dengan tujuan untuk mengumpulkan dana bagi belanja negara, di mana masyarakat tidak akan mendapatkan manfaat yang dapat dirasakan secara langsung. Lebih jauh, pengenaan iuran wajib ini dilaksanakan berdasarkan pada seperangkat undangundang sehingga dapat dipaksakan. Pendapatan negara dari pajak adalah salah satu kontributor terbesar bagi keuangan negara (Yefni et al., 2017). Sebagaimana disampaikan dalam Buku Informasi APBN 2019, pendapatan nasional Indonesia dari sektor perpajakan adalah yang unsur pendapatan paling dominan. Berdasarkan data tahun 2016, penerimaan negara dari sektor pajak bahkan telah mencapai di atas $80 \%$. Gambar 1 menyajikan grafik proporsi penerimaan negara tahun 2016 hingga 2019.

\section{Proporsi Penerimaan Negara 2016-2019}

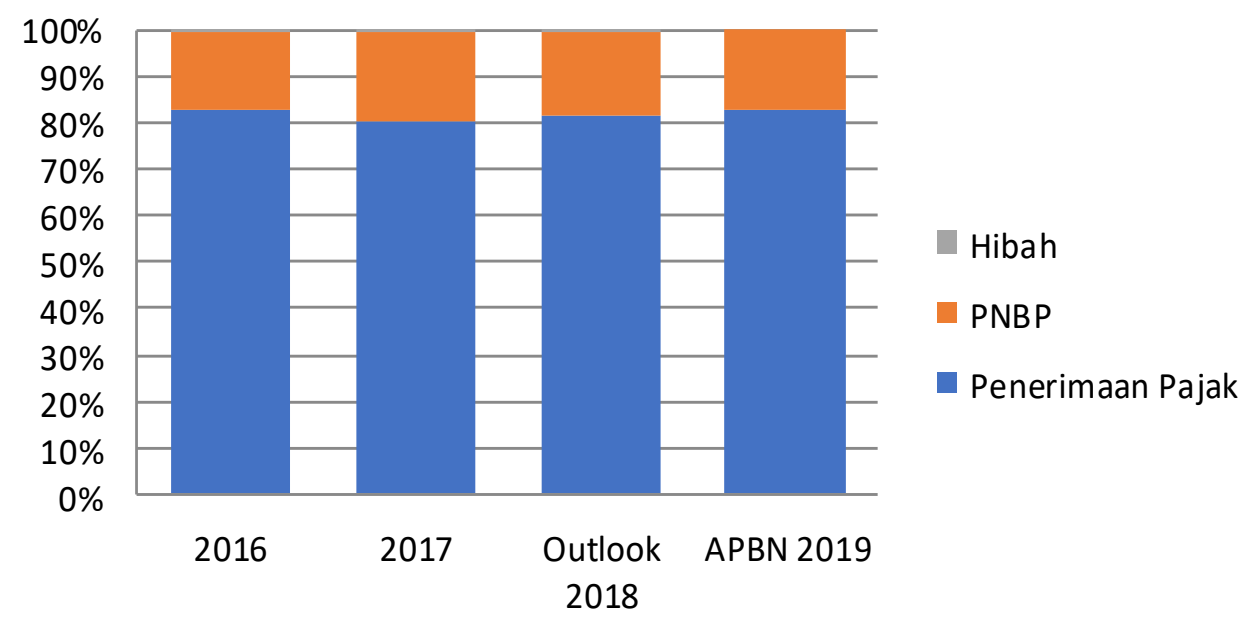

Gambar 1. Proporsi Penerimaan Negara Tahun 2016-2019.

Sumber: Informasi APBN 2019, 2019

Mengingat pajak memiliki kontribusi terbesar bagi penerimaan negara, pemerintah tidak tinggal diam dan terus menggunakan segala daya upaya untuk dapat mengoptimalkan jumlah pendapatan nasional yang bersumber dari pembayaran pajak oleh masyarakat. Melonjaknya pengeluaran (belanja) negara yang semakin meningkat setiap tahunnya, membutuhkan adanya sikap sadar serta patuh dari wajib pajak untuk bertindak sebagaimana amanat dari kaidahkaidah perpajakan, tujuannya agar pemasukan pajak tetap mampu mendanai pengeluaran negara (Lasmaya \& Fitriani, 2017).

Perilaku patuh dari wajib pajak dalam melaksanakan tanggung jawab perpajakan merupakan karateristik personal yang harus tertanam dalam benak setiap wajib pajak. Tanpa adanya sikap patuh dari wajib pajak maka mustahil bagi pemerintah untuk memperoleh pembayaran pajak yang optimal dari masyarakat dan mendapatkan penerimaan keuangan yang cukup untuk membiayai pengeluaran negara (Nerissa, 2018). Kepatuhan wajib pajak menjadi 
hal yang krusial di Indonesia karena perpajakan di Indonesia menganut sistem self-assessment. Konsekuensi dari pelaksanaan sistem ini, wajib pajak dituntut untuk mau aktif melaksanakan seluruh rangkaian pelaksanaan kewajiban perpajakannya. Secara spesifik, self-assessment system menuntut masyarakat untuk menghitung kewajiban pajak secara mandiri, memahami ketentuan peraturan perpajakan yang ada, bersikap jujur dalam melaksanakan kewajiban perpajakan, serta memiliki moral pajak yang baik sehingga memahami pentingnya pajak bagi negara. Pelaksanaan sistem self-assessment dapat dikatakan berhasil apabila masyarakat (wajib pajak) menunjukkan sikap sadar akan kaidah perpajakan serta berperilaku sebagaimana amanat regulasi perpajakan (Diamastuti, 2016). Hal serupa ditegaskan oleh (Simamora, 2015) dalam penelitiannya yang juga menyebutkan bahwa perolehan negara yang didapatkan dari pemenuhan pajak penghasilan khususnya atas wajib pajak orang pribadi ditentukan dari tepat waktunya masyarakat dalam menyampaikan surat pemberitahuan pajak, sikap kooperatif pembayar pajak untuk melakukan setoran dengan benar, dan dapat atau tidaknya wajib pajak melakukan penyetoran sesuai dengan batas waktu yang ditentukan.

Sikap patuh pajak pada dasarnya ditunjukkan dengan perilaku wajib pajak yang memegang teguh kaidah perpajakan yang berlaku. Hal ini didukung dengan hasil riset yang dilakukan oleh (Nkundabanyanga et al., 2017) yang menyatakan bahwa sikap bersedia yang ditunjukkan wajib pajak untuk memenuhi tanggung jawab perpajakannya merupakan perwujudan dari anggapan bahwa kepatuhan pajak merupakan norma yang harus ditaati. Sikap patuh terhadap ketentuan perpajakan dipengaruhi oleh beberapa faktor. Sebuah penelitian lain menegaskan bahwa patuhnya wajib pajak terhadap regulasi tentang pajak di antaranya ditentukan oleh pengetahuan seseorang tentang ilmu perpajakan, besarnya tarif pajak, denda atau hukuman atas pelanggaran pajak, dan juga rasa keadilan yang dirasakan wajib pajak (Alleyne, P., \& Harris, 2017).

Di Indonesia, ketentuan perpajakan memberikan fasilitas khusus kepada wajib pajak yang berkecimpung dalam usaha saha mikro, kecil, dan menengah (UMKM). Secara spesifik, pada bulan Juni 2018, telah diterbitkan Peraturan Pemerintah No. 23 tahun 2018 yang memberikan kemudahan bagi pelaku usaha yang berkecimpung di bidang UMKM dapat menggunakan tarif pajak penghasilan final sebesar 0,5 persen dari omset usaha. Peraturan ini sendiri menggantikan regulasi yang sebelumnya berlaku, yaitu Peraturan Pemerintah No. 46 tahun 2013 yang mengatur UMKM untuk membayar pajak sebesar 1 persen dari omset usaha. Oleh karenanya, dapat dilihat bahwa regulasi ini membawa konsekuensi terjadinya penurunan tarif pajak penghasilan di sektor UMKM. Penurunan tarif ini diterbitkan dengan maksud untuk menggiatkan masyarakat yang berkecimpung dalam kegiatan UMKM dapat mengambil peran dalam keberlangsungan kegiatan ekonomi dengan memberikan keluasaan dan kesamarataan kepada pelaku usaha dengan peredararan bruto dalam satu tahun pajak tidak melebihi 4,8 milyar (Suci et al., 2019).

Diundangkannya PP No. 23 tahun 2018 memberi impresi pada meningkatnya besaran kepatuhan wajib pajak sektor mikro kecil dan menengah di wilayah-wilayah negara Indonesia, begitu pula dengan wilayah Bali. Namun demikian, di sebagian daerah kerja kantor pelayanan pajak di Indonesia, data 
justru menunjukkan anomali: justru setelah terbitnya PP No. 23 tahun 2018 ini fase kepatuhan wajib pajak cenderung menurun. Salah satu daerah kerja kantor pelayanan pajak yang mengalami kondisi ini adalah KPP Pratama Singaraja yang berada di bawah naungan Kanwil DJP Bali. Gambar 2 berikut menyajikan grafik perbandingan pada besaran kepatuhan wajib pajak badan dan op non karyawan di cakupan kantor pelayanan pajak yang ada di lingkungan Kanwil DJP Bali antara tahun 2018 dan tahun 2017. Secara eksplisit Gambar 2 menunjukkan bahwa fase kepatuhan wajib pajak pelaku usaha mikro, kecil, dan menengah di cakupan wilayah kantor pelayanan pajak yang ada di Bali mengalami peningkatan pasca berlakunya PP No. 23 tahun 2018, terkecuali wajib pajak di yang berada di bawah naungan KPP Pratama Singaraja.

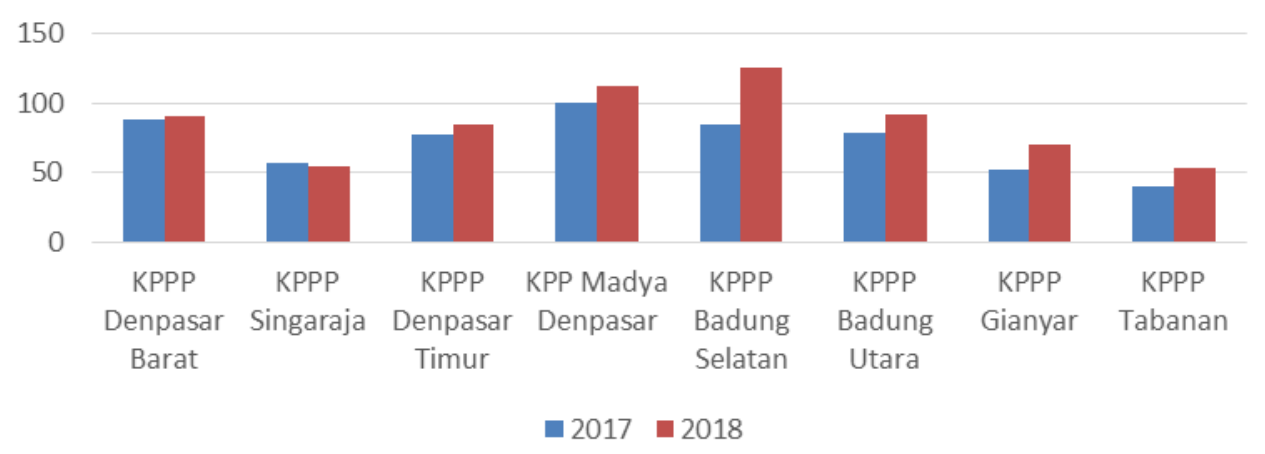

\section{Gambar 2. Tingkat Kepatuhan Wajib Pajak UMKM di KPP di Lingkungan Kanwil DJP Bali tahun 2017 dan 2018}

Sumber: Data Penelitian, 2019

Meski anomali tingkat kepatuhan wajib pajak seperti diuraikan pada Gambar 2. sangat krusial untuk diinvestigasi, penelitian yang memusatkan pada kepatuhan wajib pajak yang menjalankan kegiatan UMKM pasca diundangkannya PP No. 23 Tahun 2018 masih terbatas. Melihat pada kekosongan literatur, penelitian ini menjadi substansial untuk dilakukan. Arah dari penelitian yang dilakukan yakni untuk mengeksplorasi asal mula dari belum optimalnya fase dari kepatuhan wajib pajak pelaku UMKM untuk bertanggung jawab terhadap penyetoran pajak penghasilan walaupun fasilitas sebagaimana PP Nomor 23 Tahun 2018 telah diberikan. Di sisi lain, studi ini juga mengarah pada penyelaman persepsi wajib pajak di sektor UMKM terhadap fasilitas perpajakan sebagaimana PP Nomor 23 Tahun 2018, serta mengidentifikasi kendala yang dihadapi oleh petugas pajak dalam penerapan PP No. 23 Tahun 2018.

Penelitian ini akan dapat memberikan kebermanfaatan teoritis dan juga praktis. Kegunaan teoritis memberikan pandangan bahwa iktikad wajib pajak untuk menyetorkan sebagian penghasilannya ke negara sesuai dengan regulasi didasari atas niat dari dalam diri wajib pajak serta merasakan adanya manfaat yang diterima setelah melakukan pembayaran pajak. Enggannya sikap wajib pajak untuk patuh disebabkan ketiadaan niat serta belum timbulnya kesadaran wajib pajak untuk taat pajak. Di sisi lain, signifikansi dari uang pajak yang dibayarkan bagi keberlangsungan negara juga belum diresapi oleh wajib pajak. 
Secara praktis, penelitian ini memberi implikasi penting bagi otoritas perpajakan dalam rangka meningkatkan kepatuhan UMKM dalam melaksanakan kewajiban perpajakan. Dengan diperolehnya data mengenai penyebab belum optimalnya pembayaran pajak dari sektor UMKM di KPP Pratama Singaraja, pimpinan unit organisasi dapat menjadikan penelitian ini sebagai rujukan dalam menentukan kebijakan yang dapat memberikan dampak pada meningkatnya kesadaran dan kepatuhan wajib pajak para pelaku UMKM terhadap reglemen perpajakan.

Teori keperilakuan dijadikan landasan dalam mengamati perilaku wajib pajak yang berkecimpung di lingkup UMKM di wilayah Singaraja dalam menentukan sikap patuh atau tidaknya wajib pajak dalam menjalankan tanggungjawab perpajakan. Teori tindakan beralasan (theory of reasoned action) merupakan teori perihal keperilakuan yang diusulkan pertama kali pada tahun 1980 oleh (Ajzen \& Fishbein, 1980) Dalam teori tindakan beralasan ini dinyatakan bahwa ada korelasi antara keyakinan (belief), sikap (attitude), kehendak (intention) dan perilaku (behavior). Sikap dan norma subjektif merupakan faktor penentu kehendak dalam teori ini. Kehendak adalah dugaan terbaik yang dapat melihat perilaku yang akan dilakukan oleh seseorang. Namun untuk dapat berbuat sesuatu seseorang juga tidak harus selalu berdasar pada kehendak. Dalam theory of reasoned action tidak selaku kehendak yang dijadikan sebagai prediktor. Dalam studi yang dilakukan oleh (Untaru et al., 2016) dan (Procter et al., 2019) ditegaskan bahwa konsep utama dari theory of reasoned action ini terletak pada fokus perhatian seseorang. Hal ini memberikan arti bahwa hal yang paling urgensi-lah yang lebih dijadikan pertimbangan seseorang dalam melakukan sesuatu Tindakan, dan tidak melulu soal kehendak.

Ajzen menyempurnakan teori tindakan beralasan ini dengan teori perilaku direncanakan (theory of planned behaviour) di tahun 1991 (Ajzen, 1991, 2012). Theory of planned behaviour menyertakan determinan kontrol persepsi perilaku dalam melihat kehendak. Berbeda dari theory of reasoned action yang menyebutkan bahwa dalam berperilaku seseorang akan bertindak didasari dengan adanya niat yang ditambah dengan adanya pengaruh lingkungan sosial, teori perilaku yang direncanakan ini melihat niat dari seseorang dalam berperilaku ditentukan dari sikap seseorang ketika bertemu suatu objek, sehingga bisa memberikan penilaian apakah baik atau tidak, niat juga dipengaruhi dari norma subjektif yang dapat menimbulkan tekanan bagi seseorang untuk mau atau tidak dalam berindak dan disempurnakan dengan adanya kontrol perilaku dari seseorang yang dapat menunjukkan adanya kemudahan maupun kesulitan yang ditemukan ketika seseorang akan bertindak (Pangestie \& Satyawan, 2019).

Korelasi penerapan kedua teori keperilakuan ini dengan penelitian yang dilakukan adalah memandang bahwa kehendak atau intensi yang mendorong perilaku wajib pajak yang berkecimpung dalam bidang UMKM dalam menyetorkan sebagaian penghasilannya ke negara sebagaimana diatur oleh regulasi didasari pada adanya niat dari wajib pajak, memiliki keyakinannya akan manfaat yang diperoleh dari menyetorkan pajak ke kas negara serta adanya pengaruh maupun dorongan dari lingkungan sosial untuk taat pada regulasi perpajakan. Kemauan wajib pajak untuk menyisihkan penghasilannya untuk 
kepentingan negara juga ditentukan dari adanya kendala yang menghalangi maupun fasilitas yang diterima wajib pajak sehingga tidak merasa terbebani dalam memenuhi tanggung jawab perpajakannya.

\section{METODE PENELITIAN}

Penelitian ini adalah studi eksplorasi yang menggunakan pendekatan kualitatif dengan desain penelitian studi kasus. Setting penelitian adalah Kabupaten Buleleng yang tidak lain adalah wilayah dari KPP Pratama Singaraja. Wilayah Kerja KPP Pratama Singaraja merupakan keseluruhan wilayah Kabupaten Buleleng, yang memiliki sembilan kecamatan, yaitu: Gerokgak, Seririt, Busungbiu, Banjar, Sukasada, Buleleng, Sawan, Kubutambahan, dan Tejakula. Lokasi penelitian ditetapkan karena dari delapan kantor pelayanan pajak di lingkungan Kanwil DJP Bali, hanya KPP Pratama Singaraja yang menampakkan penurunan pada jumlah wajib pajak yang patuh terhadap aturan perpajakan setelah diundangkannya PP No. 23 tahun 2018.

Dalam studi ini, perolehan data dilakukan dengan cara wawancara dan mengumpulkan dokumen yang diperoleh dari lokasi penelitian. Untuk menetukan informan dalam penelitian ini dilakukan dengan pertimbanganpertimbangan tertentu atau yang dikenal dengan teknik purposive sampling. Sebagaimana dijelaskan oleh (Sugiyono, 2017) pemilihan informan dengan cara purposive harus didasarkan pada adanya pertimbangan tertentu sehingga orang tersebut dapat dipilih menjadi informan. Dalam penelitian ini ada 15 orang yang diwawancara. Pegawai KPP Pratama Singaraja yang memiliki tugas dan fungsi sejalan dengan tujuan penelitian ini dipilih sebanyak lima orang untuk dijadikan infroman. Wajib pajak yang menekuni bidang UMKM dengan kriteria orang pribadi atau badan dan tidak termasuk BUT yang memiliki penghasilan kotor kurang dari 4,8 milyar rupiah dalam satu tahun pajak, tidak menjalankan usaha/ pekerjaan bebas, kegiatan usahanya hanya di dalam negeri, dan memiliki NPWP di KPP Pratama Singaraja dipilih sebanyak 10 orang untuk dijadikan informan.

Semenjak diperoleh data dari lapangan baik melalui wawancara maupun dari dokumen-dokumen yang ada, data tersebut langsung dipelajari, dirangkum, ditelaah serta dianalisis sepanjang penelitian. Penelitian ini menggunakan teknik analisis data dengan mengikuti model Miles dan Huberman (Lune \& Berg, 2017), yaitu dengan menggunakan tiga jalur analisis data. Proses analisis dimulai dengan memilih dan menyederhanakan data dan juga menjadikan data kasar yang diperoleh selama penelitian ke dalam catatan lapangan atau dikenal dengan istilah reduksi data. Proses analisis dilanjutkan dengan penyajian data. Penyajian data merupakan cara dalam merangkum data sehingga dapat memudahkan untuk dapat menarik kesimpulan dari penelitan yang telah dilakukan. Proses terakhir adalah penarikan kesimpulan dan juga memverifikasi pengumpulan data yang didapat selama penelitian dilapangan.

Data yang diperoleh selama penelitian di lapangan yang telah dipisahkan kemudian disusun untuk menemukan suatu relevansi hingga sampai pada tahap menarik kesimpulan. Untuk memperkuat kesimpulan dari penelitian tentunya diperlukan verifikasi ulang. Dalam penelitian ini, untuk dapat menarik suatu kesimpulan yang valid digunakan teknik triangulasi data. Ada tiga jenis teknik 
triangulasi data, yakni triangulasi sumber yang merupakan proses memverifikasi data menggunakan berbagai sumber. Triangulasi teknik pengumpulan data merupakan proses pengecekan ulang dengan berbagai macam cara, dan triangulasi waktu digunakan untuk memvalidasi data dalam berbagai waktu (Lune \& Berg, 2017).

\section{HASIL DAN PEMBAHASAN}

Hasil penelitian di lapangan memberikan data dari dua sumber. Data pertama didapatkan dengan melakukan wawancara langsung terhadap 15 informan terpilih, yang mana pegawai di KPP Pratama Singaraja berjumlah lima orang dan wajib pajak yang dipilih merupakan wajib pajak yang telah memenuhi tolak ukur selaku wajib pajak yang mendapat perolehan dari menjalankan kegiatan usaha mikro, kecil, dan menengah dengan bruto yang tidak lebih dari yang ditetapkan undang-undang sejumlah 10 orang. Sedangkan data kedua merupakan dokumen dari kantor pelayanan pajak berupa laporan kinerja tahun 2017, laporan kinerja tahun 2018, dan laporan kinerja tahun 2019, ditambah dengan dokumentasi kegiatan sosialisasi dan penyuluhan yang dilaksanakan pada tahun 2019.

Menilik pada data laporan kinerja KPP Pratama Singaraja dari tahun 2017 sampai dengan tahun 2019, capaian kepatuhan wajib pajak badan dan orang pribadi non-karyawan terus merosot. Pada akhir tahun 2017, besaran angka patuhnya wajib pajak telah mencapai di atas $55 \%$ yakni berada pada posisi 56.92 persen. Perihal kepatuhan di KPP Pratama Singaraja pada akhir Tahun 2019 menunjukkan angka 53.36 persen yang berarti menurun sebesar 0.98 persen dari capaian tahun sebelumnya yakni sebesar 54.34 persen. Hal ini patut menjadi fokus perhatian dari pimpinan unit di KPP Pratama Singaraja, melihat dari 12.844 wajib pajak yang ada dalam sistem perpajakan di KPP Pratama Singaraja, yang telah melaksanakan tanggung jawabnya untuk melapor SPT menunjukkan angka sebesar 6.133. Angka tersebut memberikan cerminan bahwa persentase kepatuhan wajib pajak belum maksimal. Gambaran grafik penurunan fase kepatuhan wajib pajak badan dan orang pribadi non karyawan di KPP Pratama Singaraja Tahun 2017, 2018, dan 2019 terlihat secara eksplisit pada Gambar 3 di bawah ini.

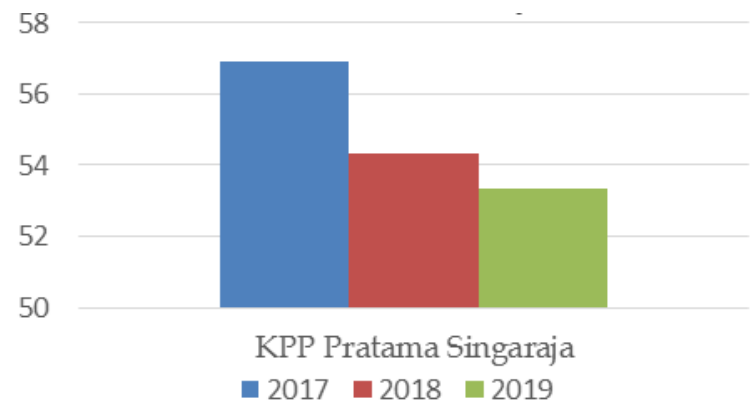

Gambar 3. Tingkat Kepatuhan WP Badan dan OP Non Karyawan di KPP Pratama Singaraja Tahun 2017-2019

Sumber: Data Penelitian, 2019 
Dalam wawancara yang dilakukan, Kepala KPP Pratama Singaraja memberikan pernyataan yang menggambarkan keadaan dimana kepatuhan wajib pajak di KPP Pratama Singaraja masih di bawah target yang diharapkan. "Masalah utama kita di Singaraja ini adalah tingkat kesadaran Wajib Pajak yang masih rendah. Mengapa hal itu terjadi? Ini karena kurangnya kita, sebagai Petugas Pajak untuk menyampaikan fungsi dan peranan pajak dalam kehidupan sehari-hari. Kuncinya adalah bagaimana kita dapat menimbulkan kesadaran bagi seluruh masyarakat akan fungsi dan peranan pajak. Kita perlu untuk mengingatkan secara terus-menerus kepada masyarakat kita. Sehingga jika sudah tertanam kesadaran dalam dirinya maka kepatuhan dari Wajib Pajak kita akan dapat meningkat."

Perihal demikian didasarkan oleh sikap Wajib Pajak yang berada di bawah naungan KPP Pratama Singaraja memang tidak sadar akan hak yang diperoleh serta kewajiban yang hendak dijalankan sebagai wajib pajak. Sadar berarti tahu atau mengerti sedangkan perpajakan adalah keadaan atau peristiwa maupun perihal yang berkenaan dengan pajak. Sehingga kesadaran perpajakan sebagaimana dikatakan (Arisandy, 2017) merupakan suatu keadaan hirau, mengetahui atau mengerti akan perihal maupun peristiwa berkenaan dengan pajak.

KPP Pratama Singaraja memiliki wajib pajak dengan perilaku yang resisten yang mana wajib pajak tidak paham akan kewajiban perpajakan secara mendalam, mereka belum memiliki kesadaran pajak. Pandangan wajib pajak selama ini adalah bahwa pajak akan menguras penghasilan mereka. Kepala KPP Pratama Singaraja, dalam wawancara, menyampaikan bahwa setiap sosialisasi agar selalu ditekankan bahwa: "Pajak memanen telurnya, bukan memotong ternaknya. Pajak itu bukan tukang potong ayam, Pajak itu ibarat memungut telur. Oleh karena itu kedepan kita harus tanamkan kepada Wajib Pajak manfaat dari uang pajak yang mereka bayarkan dan juga kita jangan lupa berterimakasih kepada Wajib Pajak atas peranan mereka menyumbang penerimaan negara."

Wajib pajak yang paham akan pengetahuan pajak berarti memiliki ilmu tentang hak yang diperoleh sebagai wajib pajak dan kewajiban apa yang harus dipenuhi. Wajib pajak mampu untuk mengetahui tentang Nomor Pokok Wajib Pajak, mengetahui tentang hukuman apa yang akan dikenakan jika melanggar aturan perpajakan, berapa besarnya tarif pajak yang dikenakan, berapa jumlah penghasilan yang tidak dikenakan pajak, dan mengetahui bagaimana cara menyetorkan pajak yang benar serta menyampaikan laporan pajak yang sesuai (Ilhamsyah et al., 2016). Dengan memiliki pengetahuan yang mumpuni tentang perpajakan, maka wajib pajak tentu akan dapat bertangung jawab terhadap pajak yang ditanggungnya.

Wawancara terhadap 10 informan wajib pajak yang menjalankan kegiatan UMKM di Singaraja menunjukkan potret bahwa penyebaran informasi tentang perpajakan yang disampaikan oleh petugas pajak belum merata ke semua wilayah. Informan yang bertempat kegiatan di wilayah kota dengan wajib pajak yang tinggal di desa tidak memperoleh hak yang sama akan informasi perpajakan. Daerah perkotaan selalu dipenuhi dengan informasi-informasi terbaru, sedangkan di luar itu, bahkan tidak ada informasi yang sampai pada wajib pajak di pedesaan. Hal ini disebakan tidak lain karena wilayah kerja yang 
luas dan sulit untuk dijangkau. Kabupaten Buleleng memang diketahui memiliki kondisi geografis yang didominasi oleh pegunungan sehingga dipenuhi medan jalan yang terjal dan berliku. Hal ini juga yang menyulitkan petugas pajak untuk dapat menjangkau seluruh wajib pajak.

Informasi yang didapat dari hasil wawancara juga memperlihatkan bagaimana wajib pajak yang berkecimpung dalam kegiatan UMKM di wilayah naungan KPP Pratama Singaraja masih ada yang tidak mengetahui sama sekali untuk apa ia membayar pajak selama ini. Informan menceritakan bahwa tidak ada manfaat yang diterimanya secara langsung ketika sudah membayar pajak ke negara sehingga timbul keengganan dari dalam diri wajib pajak untuk memberikan kontribusinya kepada negara. Hal ini menyiratkan bahwa wajib pajak selama ini tidak memiliki sikap sadar pajak. Undang-undang perpajakan Indonesia sudah menjelaskan bahwa pajak bersifat wajib dan memaksa serta tidak ada kontraprestasi langsung yang dapat diterima karena uang pajak dipergunakan sebesar-besarnya bagi kemakmuran rakyat dan tentunya untuk menjalankan roda pemerintahan. Sehingga sudah sepatutnya wajib pajak mengetahui bahwa iuran wajib yang dibayarkan ke negara bukan untuk memperoleh imbalan namun untuk membiayai pengeluaran negara.

Salah satu informan yang menjalankan usaha di Kota Singaraja menyatakan telah mengetahui adanya fasilitas tarif pajak baru yang dapat digunakan bagi wajib pajak yang menjalankan UMKM. Informan juga memberikan informasi telah membayar pajak sesuai dengan tarif baru yang difasilitasi dalam PP Nomor 23 Tahun 2018, yaitu sebagai berikut: "Saya sudah bayar pajak pakai tarif 0.5 persen karena sudah mendapatkan informasi melalui surat dan juga ada sosialisasi dari Kantor Pajak."

Satu informan lainnya yang masih berlokasi di wilayah yang sama juga menyampaikan hal serupa. Kendati telah membayar pajak menggunakan tarif terbaru sesuai ketentuan, informan tidak mengetahui akan pemanfaatan dari uang pajak yang telah dibayarkan. Informan mengakui bahwa membayar pajak karena merasa takut akan dikenakan hukuman apabila tidak menuruti aturan pajak, sebagaimana dinyatakan oleh informan: "Saya tidak mengetahui uang pajak yang saya bayar itu untuk apa, saya hanya membayar sebagaimana diberitahu pegawai pajak."

Dua orang informan, yang juga berlokasi di Kota Singaraja memberikan pernyataan bahwa telah mendapatkan informasi terkait adanya penurunan tarif pajak penghasilan final bagi pelaku UMKM baik melalui surat maupun kunjungan langsung dari petugas pajak. Namun demikian, informan menyampaikan enggan untuk membayar pajak penghasilan. Hal ini disebabkan tipisnya keuntungan usaha yang diperoleh. Informan juga menyampaikan bahwa dirinya merasa terbebani dengan harus membayar pajak penghasilan final 0,5 persen ini dikarenakan dasar penghitunganya adalah keseluruhan penghasilan kotor tanpa adanya pengurangan.

Informan lain yang memiliki toko berlokasi di Kecamatan Seririt menyatakan tidak lagi memenuhi kewajiban perpajakannya dikarenakan usaha yang dijalankan sedang merugi. Informan menyampaikan bahwa selama usahanya masih berjalan dengan baik selalu melaksanakan kewajiban 
perpajakan dengan tertib, namun saat ini tidak lagi memiliki kemampuan untuk membayar pajak, sehingga tidak lagi membayar pajak.

Pernyataan berbeda dikemukakan oleh informan lainnya yang berlokasi di daerah pedesaan. Para informan mengaku bahwa tidak mengetahui dan tidak pernah mendapatkan informasi apapun terkait perpajakan. Informan juga tidak memiliki niat untuk mencari tahu tentang kewajiban perpajakannya, sebagaimana dikatakan langsung oleh informan: "Saya tidak tahu kalau jualan harus membayar pajak juga tidak tahu cara membayar pajak dan berapa pajak yang harus dibayar. Tidak pernah ada pegawai pajak yang datang dan juga tidak pernah ada surat dari Kantor Pajak"

Sistem self assessment di wilayah ini tidak berjalan. Informan tidak memiliki peran aktif dalam pemenuhan kewajiban perpajakan. Informan menyampaikan untuk mencapai kantor pajakpun dirasa sulit dan menghabiskan banyak waktu. Para informan mengatakan bahwa pada awalnya mencari NPWP hanya sebagai persyaratan untuk memperoleh pinjaman modal usaha dan tidak mengetahui apa yang seharusnya dipenuhi sebagai wajib pajak.

Dikaitkan dengan theory of reasoned action, hasil wawancara memberikan jawaban bahwa ketidakpatuhan perilaku yang ditunjukkan wajib pajak bermula dari tidak timbulnya niat wajib pajak. Wajib pajak juga menunjukkan sikap ketidakpahaman akan norma perpajakan. Pengaruh lingkungan memiliki andil menimbulkan tidak adanya niat wajib pajak untuk menyetorkan uang pajak ke negara.

Account representative, informan dalam penelitian ini yang bertugas di wilayah kerja KPP Pratama Singaraja membenarkan bahwa penyebaran informasi kepada wajib pajak di lingkup kerja wilayah Kabupaten Buleleng belum dapat dilaksanakan dengan maksimal. Hal ini disebabkan oleh beberapa kendala, terutama adalah wilayah kerja. Wilayah Kabupaten Buleleng diketahui memiliki kondisi geografis yang bervariasi. Daerah perbukitan dan pegunungan dengan medan terjal mendominasi di selatan, sedangkan daerah pantai yang kurang landai dan sempit ada di wilayah utara. Medan seperti ini menjadi kendala bagi petugas pajak KPP Pratama Singaraja dalam menjangkau wajib pajak, demikian pula sebaliknya terutama di daerah-daerah yang terletak cukup jauh dari KPP Pratama Singaraja yang berlokasi di Pusat Kota Singaraja. Jarak dan waktu tempuh serta medan jalan yang berliku serta didominasi pegunungan mengakibatkan akses yang terbatas untuk menjangkau wajib pajak. Selain itu jumlah petugas pajak yang tidak banyak membuat semakin sulit untuk dapat menjangkau wajib pajak. Dengan kondisi seperti itu banyak hal yang menghalangi wajib pajak ataupun petugas pajak untuk menjalankan kewajiban, seperti jarak tempuh, waktu tempuh, serta keberadaan fasilitas pendukung seperti bank umum dan kantor pos yang masih sulit untuk ditemui.

Dengan kondisi geografis wilayah Kabupaten Buleleng yang beraneka ragam, menjadikan tantangan tersendiri bagi otoritas perpajakan KPP Pratama Singaraja dalam menghimpun perolehan pajak dan juga menumbuhkan sikap patuh wajib pajak terutama di era globalisasi yang kini lebih banyak menggunakan internet dalam pelayanannya. Akses internet di beberapa wilayah di Kabupaten Buleleng memang masih belum baik. Kondisi demikian memberikan pengaruh pada jumlah informasi yang dapat tersampaikan kepada 
wajib pajak dan juga sangat mempengaruhi pemanfaatan e-filling maupun layanan elektronik lainnya dalam pemenuhan pelaporan pajak. Di era modern seperti sekarang ini akses internet memang merupakan kebutuhan pokok. Sebagian layanan di Direktorat Jenderal Pajak juga kini telah beralih ke sistem elektronik yang memerlukan akses internet. Oleh sebab itulah keberadaan remote area di beberapa wilayah di Kabupaten Buleleng yang tidak memiliki koneksi internet belum dapat tersentuh oleh layanan online.

Selain itu, karakteristik resisten dari wajib pajak di lingkup KPP Pratama Singaraja menyulitkan petugas pajak dalam memberikan infromasi. Sehingga dalam membangun kesadaran Wajib Pajak tidak dapat hanya mengandalkan sosialisasi atau cara persuasif, akan tetapi juga perlu dengan melakukan penegakan hukum, hal ini ditegaskan oleh Kepala Seksi Ekstensifikasi dan Penyuluhan, sebagai berikut: "Kita lumayan sering untuk melakukan sosialisasi bagi UMKM tetapi respon wajib pajak masih sedikit, jadi jika kita gunakan sedikit paksaan maka hasilnya akan lebih efektif. “

Untuk dapat merangsang pertumbuhan kepatuhan wajib pajak yang menekuni bidang UMKM di Singaraja, Pimpinan Unit menetukan beberapa strategi. Seperti yang dijelaskan William Stanton dalam (Igam et al., 2018) strategi adalah suatu rencana dasar yang menyeluruh dari suatu tindakan yang dilakukan oleh organisasi untuk mencapai tujuan. KPP Pratama Singaraja dalam upaya peningkatan kepatuhan Wajib Pajak UMKM menggunakan sarana iklan layanan masyarakat melalui televisi dan radio. Luas wilayah dan kondisi geografis menyebabkan pemberitahuan kepada Wajib Pajak melalui surat tidak efektif. Selain itu, perbedaan nama di surat dengan nama yang dikenal dimasyarakat tidak sama menyebabkan informasi yang disampaikan melalui surat tidak sampai di tangan Wajib Pajak. Untuk menghindari hal tersebut, informasi penting terkait perpajakan akan disampaikan melalui iklan layanan masyarakat di televisi dan radio. Hal ini dinilai lebih efektif karena televisi dan radio adalah media yang dapat dijangkau oleh seluruh lapisan masyarakat terutama wajib pajak di pedesaan yang belum mendapat akses internet. Selain itu, iklan layanan masyarakat melalui radio dan televisi diharapkan dapat untuk meningkatkan pengetahuan akan fungsi dan manfaat dari uang pajak sehingga akan tumbuh kesadaran dari masyarakat untuk memenuhi kewajiban perpajakannya. Hal ini merupakan upaya KPP Pratama Singaraja dalam kaitannya menumbuhkan niat bagi wajib pajak sehingga timbul sikap sadar pajak atau behavioral belief dari dalam diri Wajib Pajak.

KPP Pratama Singaraja juga terus menyebar informasi melalui sosialisasi dan kelas pajak. Pelaksanaan kegiatan dimaksudkan agar masyarakat lebih peduli akan infromasi perpajakan. Sebagaimana dipaparkan (Susilawati \& Budiartha, 2016) bahwa apabila dalam sosialisasi peserta tidak cermat untuk menyimak informasi yang disampaikan akan cenderung memiliki sikap tidak patuh terhadap kewajiban perpajakan. Untuk dapat taat pajak, wajib pajak harus paham terhadap manfaat dan fungsi pajak. Demikian pula dengan penelitian ini. Dokumentasi dari KPP Pratama Singaraja dan hasil wawancara dengan Account Representative menunjukkan kurangnya antusiasme wajib pajak dalam menghadiri sosialisasi maupun pengarahan yang diberikan oleh petugas pajak. 
Dengan dilakukannya sosialisasi secara berkelompok, baik di kelurahan, maupun kelas pajak bagi Wajib Pajak UMKM harapan dari KPP Pratama Singaraja adalah dapat menumbuhkan niat untuk berperilaku patuh terhadap regulasi perpajakan yaitu norma subjektif sesuai dengan teori tentang keperilakuan yang menjadi dasar dalam penelitian ini. Sosialisasi dengan berbasis kearifan lokal seperti kesenian daerah ataupun budaya lokal juga perlu dilakukan sehingga masyarakat dapat merasakan bahwa Direktorat Jenderal Pajak tidak hanya merangkul pengusaha-pengusaha besar namun juga pelaku usaha kecil di daerah pelosok. Dengan semakin banyaknya masyarakat yang paham dan sadar akan kewajiban perpajakannya serta mengetahui fungsi dari pajak akan mempengaruhi sikap seseorang untuk taat pajak.

Keberadaan wajib pajak yang menyebar di seluruh pelosok Kabupaten Buleleng, disiasati oleh KPP Pratama Singraja mengadakan Pojok Pajak selama masa waktu pelaporan SPT Tahunan. Saat ini, pelaporan dapat dilaksanakan secara online melalui $e$-filling, namun dengan keterbatasan internet di beberapa wilayah Kabupetan Buleleng menyebabkan tidak semua wajib pajak dapat memanfaatkan hal tersebut. Untuk mengatasi persoalan tersebut, maka KPP Pratama Singaraja memfasilitasi wajib pajak yang hendak melaksanakan kewajibannya dengan membuka pojok pajak di beberapa area.

Salah satu bentuk control beliefs yang dapat dilakukan oleh fiskus adalah update data wajib pajak. Di KPP Pratama Singaraja masih ditemukan adanya wajib pajak non efektif yang masih ada dalam basis data, oleh karena itu pegawai pajak tentunya diharapkan terus melakukan pembaruan data sesuai dengan keadaan di lapangan sehingga data yang tersaji merupakan data valid.

\section{SIMPULAN}

Diundangkannya PP No. 23 tahun 2018 memberi impresi pada meningkatnya besaran kepatuhan wajib pajak sektor mikro kecil dan menengah di wilayahwilayah negara Indonesia, begitu pula dengan wilayah Bali. Namun demikian, data justru menunjukkan anomali. Salah satu daerah kerja kantor pelayanan pajak yang mengalami kondisi ini adalah KPP Pratama Singaraja yang berada di bawah naungan Kanwil DJP Bali. Kepatuhan Wajib Pajak justru mengalami penurunan.

Belum tumbuh sikap sadar pajak dari wajib pajak. Wajib pajak juga belum mendapati adanya manfaat dari menyetorkan pajak ke negara. Para pelaku UMKM di wilayah kerja KPP Pratama Singaraja diketahui masih enggan untuk membayar pajak penghasilan walaupun tarifnya sudah diturunkan menjadi $0,5 \%$. Wajib pajak merasa terbebani karena pajak yang harus dibayar dihitung berdasarkan keseluruhan omset usaha dan tidak adanya pengurang dalam penghitungan pajak.

Melaksanakan tugas dan fungsinya sebagai perpanjangan tangan pemerintah dalam menumbuhkan sikap patuh dari wajib pajak di daerah Kabupaten Buleleng, petugas pajak menemukan beberapa kendala, antara lain 1) wilayah kerja yang luas 2) masih terdapat remote area yang akses internetnya kurang baik, 3) keterbatasan fasilitas pendukung seperti bank dan kantor pos, dan juga 4) perilaku wajib pajak di Kabupaten Buleleng yang masih resisten dan belum memiliki kesadaran akan kewajiban perpajakan. 
Kepala KPP Pratama Singaraja menentukan strategi yang berfokus pada kesadaran wajib pajak atas signifikansi peran uang pajak bagi keberlangsungan roda pemerintahan. Masyarakat akan terus diingatkan secara berulang-ulang melalui berbagai media diharapkan akan tumbuh perilaku wajib pajak yang patuh terhadap regulasi perpajakan Indonesia.

Wilayah penelitian yang luas menyebabkan belum dapat dilaksanakannya penelitian ke semua wilayah kerja KPP Pratama Singaraja. Hal ini tentunya disebabkan oleh keterbatasan waktu dan jarak tempuh yang cukup jauh untuk menuju lokasi penelitian. Beralasan pada keterbatasan tersebut, studi selanjutnya diharapkan dapat mengeksplor keseluruhan wilayah kerja dalam cakupan KPP Pratama Singaraja. Hasilnya tentu akan lebih beragam sehingga otoritas perpajakan Indonesia dapat menerapkan langkah tepat demi kemajuan perekonomian negara.

\section{REFERENSI}

Ajzen, I. (1991). The theory of planned behavior. Handbook of Theories of Social Psychology: Volume $\quad 1, \quad$ 50, 179-211. https://doi.org/10.4135/9781446249215.n22

Ajzen, I. (2012). The theory of planned behavior. Handbook of Theories of Social Psychology: Volume 1, 211, 438-459. https://doi.org/10.4135/9781446249215.n22

Ajzen, I., \& Fishbein, M. (1980). Understanding Attitudes and Predicting Social Behavior. Pearson.

Alleyne, P., \& Harris, T. (2017). Antecedents of taxpayers' intentions to engage in tax evasion: Evidence from Barbados. Journal of Financial Reporting and Accounting, 15(1), 2-21.

Arisandy, N. (2017). Pengaruh Pemahaman Wajib Pajak, Kesadaran Wajib Pajak Dan Sanksi Pajak Terhadap Kepatuhan Wajib Pajak Orang Pribadi Yang Melakukan Kegiatan Bisnis Online Di Pekanbaru. Jumal Ilmiah Ekonomi Dan Bisnis, 14(1), 62-71.

Diamastuti, E. (2016). Ke (Tidak) Patuhan Wajib Pajak: Potret Self Assessment. Ekuitas: Jurnal Ekonomi Dan Keuangan, 20(3), 280-304.

Igam, M., Mustakim, \& Purwati, N. E. (2018). Strategi Meningkatkan Kepatuhan Wajib Pajak Di Kantor Pelayan Pajak Pratama (KKP) Kendari. Jurnal BUSINESS UHO: Jurnal Administras Bisnis. Faculty of Social and Political Sciences, Halu Oleo University Kendari. Southeast Sulawesi. Indonesia. , 3(2), 241250.

Ilhamsyah, R., Endang, M. G. W., \& Dewantara, R. Y. (2016). Pengaruh Pemahaman Dan Pengetahuan Wajib Pajak Tentang Peraturan Perpajakan, Kesadaran Wajib Pajak, Kualitas Pelayanan, Dan Sanksi Perpajakan Terhadap Kepatuhan Wajib Pajak Kendaraan Bermotor (Studi Samsat Kota Malang). Jurnal Perpajakan (JEJAK), 8.

Informasi APBN 2019. (2019). https://doi.org/10.35592/jrb.v2i2.403

Lasmaya, S. M., \& Fitriani, N. N. (2017). Pengaruh Self Assessment System terhadap Kepatuhan Wajib Pajak. Jurnal Computech $\mathcal{E}$ Bisnis, 11(2), 69-78.

Lune, H., \& Berg, B. L. (2017). Qualitative Research Methods for the Social Sciences. Pearson. 
Nerissa, A. D. I. W. (2018). Faktor-Faktor yang Mempengaruhi Kepatuhan Wajib Pajak Orang Pribadi. Jurnal Muara Ilmu Ekonomi Dan Bisnis, 2, 146-154.

Nkundabanyanga, S. K., Mvura, P., Nyamuyonjo, D., Opiso, J., \& Nakabuye, Z. (2017). Tax compliance in a developing country: Understanding taxpayers' compliance decision by their perceptions. Journal of Economic Studies, 44(6), 931-957. https://doi.org/10.1108/JES-03-2016-0061

Pangestie, D. D. :, \& Satyawan, M. D. (2019). Aplikasi Theory of Planned Behaviour: Kepatuhan Wajib Pajak Dalam Membayar Pajak Bumi dan Bangunan Di Kota Surabaya. AKUNESA: Jurnal Akuntansi Unesa, 8(1), 1-10.

Procter, L., Angus, D. J., Blaszczynski, A., \& Gainsbury, S. M. (2019). Understanding use of consumer protection tools among Internet gambling customers: Utility of the Theory of Planned Behavior and Theory of Reasoned Action. Addictive Behaviors, 99, 1-7. https://doi.org/10.1016/j.addbeh.2019.106050

Simamora, P. (2015). Pengaruh Tingkat Kepatuhan Wajib Pajak Orang Pribadi Terhadap Penerimaan Pajak Penghasilan Orang Pribadi Pada KPP Pratama Cibinong. JIMFE (Jurnal Ilmiah Manajemen Fakultas Ekonomi), 1(1), 25-31.

Suci, T. S. M., Karamoy, H., \& Rondonuwu, S. (2019). Efektivitas Penerapan Peraturan Pemerintah No.23 Tahun 2018 Terhadap Tingkat Pertumbuhan Wajib Pajak Dan Penerimaan PPh Final Pada KPP Pratama Manado. Jurnal Riset Akuntansi, 14(23), 362-370.

Sugiyono. (2017). Metode Penelitian Kuantitatif, Kualitatif, dan RED. Alfabeta, CV. Susilawati, K. E., \& Budiartha, K. (2016). Pengaruh Kesadaran, Sosialisasi, Akuntabilitas Pelayanan Publik Dan Sanksi Perpajakan Pada Kepatuhan Wajib Pajak Kendaraan Bermotor. E-Jurnal Akuntansi, 16(3), 2342-2373.

Tene, J. H., Sondakh, J. J., \& Warongan, J. D. L. (2017). Pengaruh Pemahaman Wajib Pajak, Kesadaran Pajak, Sanksi Perpajakan dan Pelayanan Fiskus Terhadap Kepatuhan Wajib Pajak (Studi Empiris Pada Wajib Pajak Orang Pribadi yang Terdaftar di KPP Pratama Manado). Jurnal Ekonomi, Manajemen, Bisnis, Dan Akuntansi, 5(2), 443-453.

Untaru, E., Ispas, A., Candrea, A. N., \& Luca, M. (2016). Predictors of individuals' intention to conserve water in a lodging context: The application of an extended Theory of Reasoned Action. International Journal of Hospitality Management, 59, 50-59. https://doi.org/10.1016/j.ijhm.2016.09.001

Yefni, Y., Gunawan, M. H., \& Nurulita, S. (2017). Government Regulation 46/2013 As Income Tax Income Facility. Jurnal Akuntansi Multiparadigma, 8(3), 600-611. https://doi.org/10.18202/jamal.2017.12.7076 